\title{
Prediksi Harga Saham Harian Menggunakan Cascade Forward Neural Network (CFNN) dengan Particle Swarm Optimization (PSO)
}

\author{
YUNITA PIPIET SUGANDHI ${ }^{1}$, BUDI WARSITO ${ }^{2}$, ARIEF RACHMAN HAKIM ${ }^{3}$ \\ 1,2,3 Departemen Statistika, Fakultas Sains dan Matematika, Universitas Diponegoro \\ email: 1yunitapipiet@gmail.com; 2budiwrst2@gmail.com; 3arief.rachman@live.undip.ac.id
}

\begin{abstract}
ABSTRAK
Jaringan Syaraf Tiruan (JST) merupakan suatu sistem pemrosesan informasi yang karakteristik dan cara kerjanya mirip dengan otak manusia. Jaringan Syaraf Tiruan dapat digunakan sebagai salah satu metode untuk peramalan tanpa harus memenuhi berbagai asumsi seperti pada metode ARIMA. Feed Forward Neural Netwok (FFNN) merupakan salah satu model jaringan syaraf tiruan yang mempunyai arsitektur jaringan sederhana, dimana hubungan antara input dan output terjadi secara tidak langsung yaitu melalui hidden layer. Cascade Forward Neural Network (CFNN) merupakan jaringan syaraf tiruan yang memiliki arsitektur mirip dengan Feed Forward Neural Netwok (FFNN), tetapi terdapat hubungan langsung antara input dan output. CFNN dapat dikombinasikan dengan berbagai metode optimasi seperti Particle Swarm Optimization (PSO). Particle Swarm Optimization (PSO) terinspirasi dari kawanan burung yang terbang berkelompok. Perpaduan antara Cascade Forward Neural Network (CFNN) dan Particle Swarm Optimization (PSO) bertujuan untuk mendapatkan bobot optimum yang meminimumkan error. Pada penelitian ini, data yang digunakan adalah data harga saham harian PT. XL Axiata Tbk. Berdasarkan hasil perhitungan menggunakan CFNN dengan optimasi PSO diperoleh MAPE training sebesar 1,8248\% dan MAPE testing sebesar 2,3136\% dimana nilai MAPE tersebut masih kurang dari 10\% sehingga keakuratan model dikatakan sangat baik.
\end{abstract}

Kata kunci: cascade forward neural network, peramalan, saham, particle swarm optimization, time series

\begin{abstract}
Artificial Neural Network (ANN) is an information-processing system which characteristics and how it worked are similar to human brain. ANN can be used as one of the forecasting method without having to fulfill various assumption suc as ARIMA method. Feed Forward Neural Network (FFNN) is one of the ANN model that have a simple network architecture, where the connection between input and output occurs indirectly through the hidden layer. Cascade Forward Neural Network (CFNN) is ANN that its architecture similar to Feed Forward Neural Network (FFNN), but there is also a direct connection between input layer and output layer. CFNN can be combined with various optimization method such as Particle Swarm Optimization (PSO). Particle Swarm Optimization (PSO) inspired by flocks of birds flying in groups. Combination between Cascade Forward Neural Network (CFNN) and Particle Swarm Optimization (PSO) aimed to obtain optimum weight that minimize error. In this study, the data used was daily stock price of PT. XL Axiata Tbk. Based on the calculation results using CFNN with PSO obtained MAPE of training data equal to $1,8248 \%$ and MAPE of testing data equal to $2,3136 \%$, which MAPE value is still less than $10 \%$ so the accuracy of the model is considered very good.
\end{abstract}

Keywords: cascade forward neural netwok, forecasting, stock price, particle swarm optimization, time series

\section{PENDAHULUAN}

Jaringan Syaraf Tiruan (JST) merupakan sistem pemroses informasi yang memiliki karakteristik mirip jaringan syaraf pada makhluk hidup. Warsito (2009) menjelaskan bahwa prinsip dari pemodel neural network dikembangkan dari karakteristik dan cara kerja orak 
manusia, dimana dalam memproses informasi otak manusia terdiri dari sejumlah neuron yang melakukan tugas sederhana. Adanya keterhubungan antar neuron menyebabkan otak manusia dapat melakukan fungsi pemrosesan yang sangat kompleks. Terdapat beberapa model neural network salah satunya adalah Cascade Forward Neural Network (CFNN). Model CFNN adalah model NN yang memiliki arsitektur jaringan mirip dengan FFNN. Jika pada FFNN tidak terdapat hubungan langsung antara input layer dengan output layer, maka pada CFNN terdapat hubungan langsung antara input layer dengan output layer.

Pada umunya CFNN dilatih menggunakan algoritma backpropagation untuk memperoleh bobot-bobotnya. Algoritma backprapogation memiliki kemampuan untuk memperoleh solusi optimum lokal tetapi kemampuan untuk memperoleh solusi optimum global sangat lemah. Solusi untuk masalah tersebut adalah melatih CFNN menggunakan optimasi Particle Swarm Optimization (PSO).

Particle Swarm Optimization (PSO) adalah teknik optimasi berbasis populasi yang dikembangkan oleh James Kennedy dan Russ Eberhart pada tahun 1995. PSO didasarkan pada tingkah laku sosial pada kawanan burung yang terbang berkelompok. Suyanto (2014) menjelaskan bahwa PSO dimulai dengan sekumpulan partikel (solusi) yang dibangkitkan secara acak. Setiap partikel kemudian dievaluasi kualitasnya menggunakan fungsi fitness. Selanjutnya, partikel-partikel akan terbang mengikuti partikel yang optimum.

Peramalan data time series pada umunya menggunakan metode Autoregressive Integrated Moving Average (ARIMA). Metode tersebut memiliki banyak asumsi yang harus dipenuhi seperti stasioneritas data, autokorelasi residual dan normalitas residual. Akan tetapi dalam praktiknya banyak terdapat data terutama data finansial yang tidak dapat memenuhi asumsi tersebut. Hal tersebut menunjukkan adanya kelemahan model ARIMA untuk digunakan sebagai alat prediksi. Kondisi inilah yang mendorong untuk mencoba menggunakan model CFNN dengan optimasi PSO untuk prediksi data harga saham.

Berdasarkan uraian tersebut, maka dalam penelitian ini dilakukan Prediksi Harga Saham Harian Menggunakan Cascade Forward Neural Network (CFNN) dengan Particle Swarm Optimization (PSO) pada harga saham harian PT. XL Axiata Tbk.

\section{TINJAUAN PUSTAKA}

\section{Saham}

Menurut Darmadji dan Fakhruddin (2001), saham merupakan tanda penyertaan atau kepemilikan seseorang atau badan dalam suatu perusahaan atau perseroan terbatas. Wujud saham adalah selembar kertas yang menerangkan bahwa pemilik kertas tersebut adalah pemilik perusahaan yang menerbitkan surat berharga tersebut. Porsi kepemilikan ditentukan oleh seberapa besar pernyertaan yang ditanamkan di perusahaan tersebut.

\section{Time Series}

Menurut Makridarkis dan Wheelwright (1999), runtun waktu (time series) adalah suatu rangkaian variabel yang diamati pada interval waktu yang sama ditunjukkan sebagai sebuah deret berkala. Analisis runtun waktu berguna untuk menentukan pola data masa lampau yang telah dikumpulkan secara teratur. Apabila telah dapat menentukan pola data tersebut, maka dapat digunakan sebagai peramalan dalam rangka pengambilan keputusan di masa datang.

\section{Autocorrelation Function (ACF)}

Menurut Wei (2006), pada suatu runtun waktu yang stasioner terdapat nilai mean $E\left(Z_{t}\right)=\mu$ dan varian $\operatorname{Var}\left(Z_{t}\right)=E\left(Z_{t}-\mu\right)^{2}=\sigma^{2}$ yang konstan. Kovarian antara $Z_{t}$ dan $Z_{t-k}$ adalah sebagai berikut:

$$
\begin{aligned}
\gamma_{k} & =\operatorname{cov}\left(Z_{t}, Z_{t-\bar{k}}\right)=E\left(Z_{t}-\mu\right)\left(Z_{t-\bar{k}}-\mu\right) \\
& =\frac{1}{n} \sum_{t=1}^{n}\left(Z_{t}-\bar{Z}\right)\left(Z_{t-\bar{k}}-\bar{Z}\right)
\end{aligned}
$$




$$
=\frac{1}{n-k} \sum_{t=1}^{n-k}\left(Z_{t}-\bar{Z}\right)\left(Z_{t-\bar{k}}-\bar{Z}\right)
$$

dengan $\operatorname{Var}\left(Z_{t}\right)=\operatorname{Var}\left(Z_{t-k}\right)=\gamma_{0}$.

Koefisien korelasi untuk lag-k dari data runtun waktu dinyatakan sebagai berikut:

$\rho_{k}=\frac{\operatorname{cov}\left(Z_{t}, Z_{t-k}\right)}{\sqrt{\operatorname{var}\left(Z_{t}\right)} \sqrt{\operatorname{var}\left(Z_{t}\right)}}=\frac{E\left(Z_{t}-\mu\right)\left(Z_{t-k}-\mu\right)}{\sqrt{E\left(Z_{t}-\mu\right)^{2}} \sqrt{E\left(Z_{t-k}-\mu\right)^{2}}}=\frac{\gamma_{k}}{\gamma_{0}}$

dengan:

$\mu \quad=$ rata-rata

$\gamma_{k} \quad=$ autokovariansi pada lag-k

$\gamma_{0}=$ autokovariansi pada lag- $\mathrm{k}$

$t \quad=$ waktu pengamatan, $\mathrm{t}=1,2,3, \ldots$

Koefisien korelasi $\rho_{k}$ dapat diduga dengan koefisien korelasi sampel sebagai berikut:

$\hat{\rho}_{k}=\frac{\gamma_{k}}{\gamma_{n}}=\frac{\sum_{t=1}^{n-\bar{k}}\left(z_{t}-\bar{Z}\right)\left(z_{t-\bar{k}}-\bar{Z}\right)}{\sum_{t=1}^{n-\bar{k}}\left(z_{t}-\bar{Z}\right)^{2}}$

dengan

$\hat{\rho}_{k} \quad=$ koefisien autokorelasi pada lag $-k$

$k \quad=$ selisih waktu

$\mathrm{n} \quad=$ jumlah observasi

$\bar{Z} \quad$ = rata-rata dari pengamatan

$Z_{t} \quad=$ pengamatan pada waktu ke- $t$

$Z_{t-k}=$ pengamatan pada waktu ke $t-k$

Plot Autocorrelation Function (ACF) digunakan untuk menentukan proses Moving Average (MA) yaitu dengan melihat lag-lag yang signifikan pada batas plot ACF.

\section{Partial Autocorrelation Fuction (PACF)}

Menurut Soejoeti (1987), autokovariansi merupakan variansi bersama dari variabel yang sama, dalam hal ini adalah data runtun waktu itu sendiri. Autokovariansi dapat dicari dengan menggunakan fungsi autokorelasi parsial (PACF). PACF didefinisikan sebagai $\left\{\emptyset_{k k} ; k=1,2, \ldots\right\}$, yaitu himpunan fungsi autokorelasi parsial untuk berbagai lag $\mathrm{k}$ dengan rumus sebagai berikut:

$\emptyset_{k k}=\frac{\left\|P_{o w k}^{*}\right\|}{\left|P_{w k k}\right|}$, untuk $\mathrm{k}=1,2, \ldots$

$\operatorname{dimana} P_{\sim k}=\left[\begin{array}{ccccc}1 & \rho_{1} & \rho_{2} & \cdots & \rho_{k-1} \\ \rho_{1} & 1 & \rho_{1} & \cdots & \rho_{k-2} \\ \rho_{2} & \rho_{1} & 1 & \cdots & \rho_{k-3} \\ \vdots & \vdots & \vdots & & \vdots \\ \rho_{k-1} & \rho_{k-2} & \rho_{k-3} & \cdots & 1\end{array}\right]$ 


\section{Yunita Pipiet Sugandhi dkk.}

$P_{\sim k} \quad:$ matriks autokorelasi $k \times k$

$P_{\propto k}^{*}: P_{\propto k}$ dengan kolom terakhir diganti dengan $\left[\begin{array}{c}\rho_{1} \\ \rho_{2} \\ \ldots \\ \rho_{k}\end{array}\right]$

Plot Partial Autocorrelation Function (PACF) digunakan untuk menentukan proses Autoregresive (AR) yaitu dengan melihat lag-lag yang signifikan pada batas plot PACF.

\section{Neural Nerwork}

Haykin (1994) menyatakan bahwa Jaringan Syaraf Tiruan (JST) atau Neural Network (NN) terinspirasi dari cara kerja otak manusia yang sangat berbeda dengan komputer digital pada umumnya. Otak manusia sangat kompleks, tidak linier dan bersifat paralel dalam hal memproses informasi. Otak manusia juga mempunyai kemampuan untuk mengatur unsur struktural yang dikenal dengan neuron, sehingga sejauh ini dalam memproses informasi otak manusia jauh lebih cepat daripada komputer digital yang ada pada saat ini. JST memiliki dua tahap pemrosesan informasi, yaitu tahap penelitian dan tahap pengujian. Warsito (2009) menjelaskan bahwa tahap pelatihan dimulai dengan memasukkan pola-pola belajar (data latih) ke dalam jaringan. Dengan menggunakan pola-pola ini, jaringan akan mengubah-ubah bobot yang menjadi penghubung antar node, sedangkan tahap pengujian dilakukan terhadap suatu pola masukan yang belum pernah dilatihkan sebelumnya (data uji) dengan menggunakan bobot hasil tahap pelatihan. Diharapkan bobot-bobot hasil pelatihan yang sudah menghasilkan error minimal juga akan memberikan error yang kecil pada tahap pengujian.

Menurut Kusumadewi (2003), NN memiliki komponen-komponen utama yang terdiri dari input, fungsi aktivasi, neuron, bias dan threshold, hidden layer, output. Dalam NN terdapat susunan dari neuron-neuron dalam lapisan yang mempunyai pola keterhubungannya dalam dan antar lapisan yang disebut dengan arsitektur jaringan. NN biasanya terdiri dari lapisan input (input layer), lapisan tersembunyi (hidden layer) dan lapisan output (output layer). Feed Forward Neural Network (FFNN) adalah salah satu model NN yang mempunyai arsitektur jaringan cukup sederhana dengan satu lapisan tersembunyi (hidden layer).

\section{Cascade Forward Neural Network (CFNN)}

Warsito et al (2018) menjelaskan jika hubungan yang terbentuk dari perceptron dan multi layer network dikombinasikan, maka akan terbentuk jaringan dengan hubungan langsung antara input layer dan output layer, selain hubungan tidak langsung yang terbentuk antara input layer dan output layer yaitu melalui hidden layer. Jaringan yang terbentuk dari pola hubungan tersebut disebut dengan Cascade Forward Neural Network.

Arsitekstur jaringan Cascade Forward Neural Network (CFNN) hampir serupa dengan Feed Forward Neural Network (FFNN). Pada FFNN hubungan input dan output bukan merupakan hubungan langsung, sedangkan pada CFNN terdapat hubungan langsung antara input dan output.

Persamaan yang terbentuk dari model CFNN dengan satu unit output layer dapat ditulis sebagai berikut:

$y=\sum_{i=1}^{I} f^{i} u_{i k} x_{i}+f^{0}\left(w_{o k}+\sum_{j=1}^{I} w_{j k} f^{j}\left(v_{o j}+\sum_{j=1}^{I} \sum_{i=1}^{I} v_{i j} x_{i}\right)\right)$

dengan:

$v_{i j} \quad$ : bobot untuk hubungan antara unit-unit pada input layer ke-i dan unit-unit pada hidden layer ke-j

$w_{i k} \quad$ : bobot untuk hubungan antara unit-unit pada hidden layer ke-j dan unit pada output layer ke-k

$u_{i k} \quad$ : bobot untuk hubungan antara unit-unit pada input layer ke-i dan unit pada output layer ke-k 
$v_{o j} \quad:$ bobot bias pada input layer ke hidden layer ke-j

$w_{\text {ok }} \quad$ : bobot bias pada hidden layer ke output layer ke-k

$f^{j} \quad$ : fungsi aktivasi yang digunakan pada hidden layer

$f^{0} \quad$ : fungsi aktivasi yang digunakan pada output layer

$f^{i} \quad$ : fungsi aktivasi yang digunakan pada input layer ke output layer

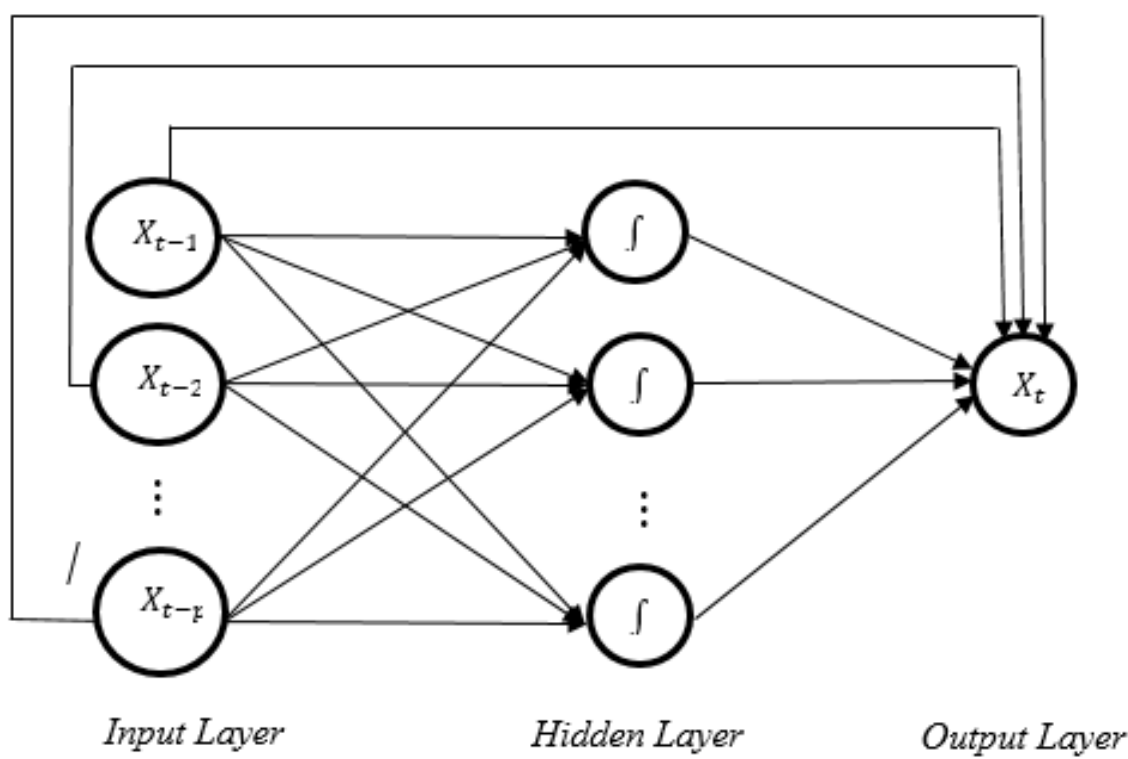

Gambar 1. Arsitektur Cascade Forward neural Network

\section{Particle Swarm Optimization (PSO)}

Menurut Suyanto (2014), Swarm Intelligent (SI) merupakan suatu disiplin ilmu yang berhubungan dengan alam dan sistem-sistem buatan yang tersusun atas banyak individu yang berkoordinasi menggunakan kontrol terdesentralisasi dan dapat mengorganisasi diri sendiri (self-organization). Secara khusus, disiplin ilmu ini fokus pada tingkah laku kolektif yang dihasilkan dari interaksi lokal antara satu individu dengan individu lain dan antara individu dengan lingkungannya. Logika Swarm Intelligent (SI) kemudian menginspirasi sebagian besar peneliti untuk mengembangkan algoritma berdasarkan pada kecerdasan binatang, terutama untuk mengatasi permasalahan optimasi. Berbagai algoritma mengenai perilaku kolektif diusulkan untuk mengatasi permasalahan optimasi. Permasalahan optimasi mengarah pada studi untuk menentukan nilai minimal ataupun maksimal dari sebuah fungsi. Nilai maksimal atau minimal tersebut disebut sebagai nilai optimal. Menurut Santosa (2017), ada dua jenis nilai optimal, yaitu global optimum dan local optimum. Sebagian besar algoritma optimasi dibuat dengan tujuan mencari nilai global optimum.

Salah satu algoritma Swarm Intelligent (SI) adalah Particle Swarm Optimization (PSO). Particle Swarm Optimization (PSO) adalah teknik optimasi populasi yang dikembangkan oleh James Kennedy dan Russ Eberhart pada tahun 1995. Teknik ini terinspirasi oleh tingkah laku sosial pada kawanan burung yang terbang berduyun-duyun atau pada segerombolan ikan yang berenang berkelompok membentuk formasi tertentu tanpa bertabrakan satu sama lain meskipun jarak antar individu begitu dekat (Suyanto, 2014). Setiap burung dianggap sebagai partikel yang merepresentasikan solusi dari suatu permasalahan yang memiliki posisi $(X)$ dan kecepatan (v). Particle Swarm Optimization (PSO) memiliki dua fungsi utama, yaitu update kecepatan dan update posisi yang digunakan untuk memperbarui kecepatan dan posisi 
partikel sehingga akan terus dipercepat sampai mendekati posisi partikel terbaik dari partikel tersebut (local best) dan partikel terbaik dari seluruh kawanan (global best) sampai kondisi minimum error tercapai. PSO dimulai dengan sekumpulan partikel (solusi) yang dibangkitkan secara acak. Berikut ini merupakan rumus perhitungan PSO:

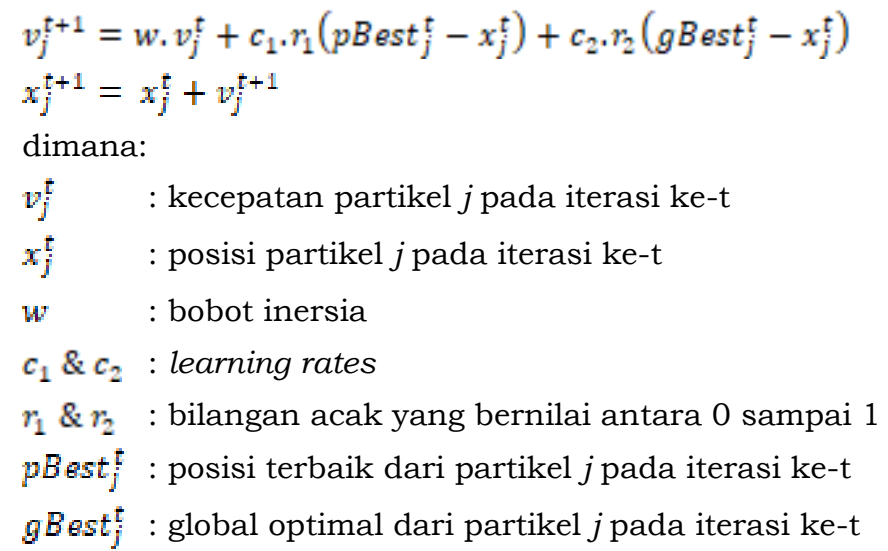

\section{METODOLOGI PENELITIAN}

\section{Jenis dan Sumber Data}

Data yang digunakan dalam penelitian ini adalah data sekunder yang diperoleh dari website Yahoo finance. Data tersebut merupakan data harga saham penutupan (harian) PT. XL Axiata Tbk periode 1 Januari 2016 sampai dengan 31 Desember 2018 dengan menggunakan hari aktif.

\section{Variabel Penelitian}

Variabel yang digunakan dalam penelitian ini adalah data harga saham penutupan (harian) PT. XL Axiata Tbk periode 1 Januari 2016 sampai dengan 31 Desember 2018 yang terdiri dari 754 data.

\section{Langkah-Langkah Penelitian}

1. Pengumpulan data saham harian PT. XL Axiata Tbk terhitung mulai dari periode 1 Januari 2016 sampai dengan 31 Desember 2018 dengan menggunakan hari aktif.

2. Menentukan nilai input berdasarkan plot PACF (Partial Auto Correlation Function).

3. Melakukan pembagian data menjadi 2, yaitu data training dan data testing.

4. Menentukan jumlah neuron hidden layer.

5. Menentukan banyaknya partikel $(N)$, nilai $c_{1}$ dan $c_{2}$ serta bobot inersia pada PSO.

6. Menginisialisasi bobot sebagai partikel pada PSO.

7. Mengevaluasi bobot dengan PSO

a. Mengevaluasi nilai fitness dari setiap partikel.

b. Memperbarui nilai pBest (posisi terbaik) dan gBest (global optimal).

c. Memperbarui kecepatan dan posisi dari setiap partikel dengan cara iterasi.

d. Jika nilai fitness antar partikel tersebut memenuhi konvergen maka iterasi akan berhenti. Jika tidak lanjutkan ke iterasi selanjutnya dengan cara yang sama.

8. Menentukan bobot akhir, dimana algoritma PSO ini akan membantu mencari bobot yang dapat menghasilkan MSE terkecil.

9. Melakukan proses testing.

10. Melakukan peramalan untuk beberapa periode ke depan. 
Tabel 1. Nilai MAPE Pembagian Data dan Jumlah Neuron Hidden Layer

\begin{tabular}{|c|c|c|c|}
\hline Pembagian Data & Jumlah Neuron & MAPE Training (\%) & MAPE Testing (\%) \\
\hline \multirow{10}{*}{$\begin{array}{l}60 \% \text { data training } \\
40 \% \text { data testing }\end{array}$} & 1 & 1,8422 & 2,2034 \\
\hline & 2 & 1,8425 & 2,2094 \\
\hline & 3 & 1,8322 & 2,1997 \\
\hline & 4 & 1,8357 & 2,1936 \\
\hline & 5 & 1,8349 & 2,2014 \\
\hline & 6 & 1,8380 & 2,2105 \\
\hline & 7 & 1,8371 & 2,1927 \\
\hline & 8 & 1,8284 & 2,1841 \\
\hline & 9 & 1,8391 & 2,2272 \\
\hline & 10 & 1,8335 & 2,1976 \\
\hline \multirow{10}{*}{$\begin{array}{l}70 \% \text { data training } \\
30 \% \text { data testing }\end{array}$} & 1 & 1,8330 & 2,3407 \\
\hline & 2 & 1,8334 & 2,3411 \\
\hline & 3 & 1,8270 & 2,3324 \\
\hline & 4 & 1,8293 & 2,3244 \\
\hline & 5 & 1,8248 & 2,3136 \\
\hline & 6 & 1,8476 & 2.3370 \\
\hline & 7 & 1,8504 & 2,3749 \\
\hline & 8 & 1,8265 & 2,3198 \\
\hline & 9 & 1,8337 & 2,3381 \\
\hline & 10 & 1,8379 & 2,3489 \\
\hline \multirow{10}{*}{$\begin{array}{c}80 \% \text { data training } \\
20 \% \text { data testing }\end{array}$} & 1 & 1,9262 & 2,1747 \\
\hline & 2 & 1,9385 & 2,1825 \\
\hline & 3 & 1,9223 & 2,1767 \\
\hline & 4 & 1,9254 & 2,1779 \\
\hline & 5 & 1,9240 & 2,1735 \\
\hline & 6 & 1,9335 & 2,1821 \\
\hline & 7 & 1,9311 & 2,1653 \\
\hline & 8 & 1,9216 & 2,1743 \\
\hline & 9 & 1,9194 & 2.1933 \\
\hline & 10 & 1,9302 & 2,1799 \\
\hline \multirow{10}{*}{$\begin{array}{c}90 \% \text { data training } \\
10 \% \text { data testing }\end{array}$} & 1 & 1,9821 & 2,0684 \\
\hline & 2 & 1,9817 & 2,0666 \\
\hline & 3 & 1,9677 & 2,0488 \\
\hline & 4 & 1,9696 & 2,0518 \\
\hline & 5 & 1,9712 & 2,0525 \\
\hline & 6 & 1,9714 & 2,0505 \\
\hline & 7 & 1,9758 & 2,0561 \\
\hline & 8 & 1,9671 & 2,0456 \\
\hline & 9 & 1,9823 & 2,0511 \\
\hline & 10 & 1,9886 & 2,0720 \\
\hline
\end{tabular}

\section{HASIL DAN PEMBAHASAN}




\section{Penentuan Input}

Penentuan input jaringan dilakukan dnegan menggunakan plot PACF. Hal ini dikarenakan plot PACF digunakan untuk menentukan proses Autoregressive (AR), dimana proses AR menggambarkan bahwa data masa kini dipengaruhi oleh data peride sebelumnya. Input jaringan berdasarkan lag-lag yang signifikan pada plot PACF yang dapat dilihat dari garis yang melewati batas plot PACF. Berdasarkan plot PACF diperoleh 1 variabel lag yang akan dijadikan input, yaitu lag 1 atau dapat dikatakan bahwa $x_{t}$ dipengaruhi oleh $x_{t-1}$ sehingga data yang digunakan sebagai input ada sebanyak 753 data yang akan dilatih dengan jaringan CFNN.

\section{Pembagian Data dan Penentuan Jumlah Neuron pada Hidden Layer}

Dalam penelitian ini penentuan pembagian data training dan data testing serta jumlah neuron pada hidden layer dilakukan dengan trial and error menggunakan CFNN dengan algoritma PSO. Selanjutnya, pemilihan perbandingan pembagian data dan jumlah neuron pada hidden layer dilihat dari MAPE training terkecil. Hasilnya disajikan dalam Tabel 1. Berdasarkan Tabel 1 dapat dilihat bahwa nilai MAPE training terkecil adalah 1,8248\% yaitu pada pembagian data $70 \%$ data training dan 30\% data testing dengan jumlah hidden layer sebanyak 5 neuron.

\section{Arsitektur Jaringan CFNN}

Berdasarkan pada percobaan pembagian data dan penentuan jumlah neuron pada hidden layer, maka arsitektur jaringan yang terbentuk terdiri dari 1 neuron pada input layer, 1 unit hidden layer yang terdiri dari 5 neuron, 1 neuron pada output layer dan melibatkan bias. Sedangkan fungsi aktivasi yang digunakan pada hidden layer adalah sigmoid bipolar dan fungsi aktivasi yang digunakan pada output layer adalah fungsi pureline.

Berdasarkan arsitektur jaringan CFNN yang telah terbentuk maka jumlah bobot atau parameter yang akan diestimasi dengan menggunakan PSO sebanyak 17 bobot terdiri dari 5 bobot memberikan sinyal input ke hidden layer, 5 bobot bias untuk hidden layer, 5 bobot neuron dari hidden layer ke output layer, 1 bobot neuron dari input layer ke output layer, 1 bobot bias untuk output layer.

\section{Proses Training CFNN dengan Algoritma PSO}

Ada beberapa hal yang harus ditetapkan terlebih dahulu sebelum memulai algoritma PSO diantaranya:

\section{Jumlah Partikel $(N)$}

Untuk mengurangi evaluasi fungsi yang diperlukan untuk menemukan solusi, sebaiknya ukuran $N$ tidak terlalu besar tetapi juga tidak terlalu ekcil. Pada penelitian ini, jumlah partikel $(N)$ yang digunakan adalah 20 partikel.

\section{Nilai $c_{1}$ dan $C_{2}$}

Pada penelitian ini, nilai $c_{1}$ dan $c_{2}$ yang digunakan adalah $2\left(c_{1}=c_{2}=2\right)$.

3. Bobot Inertia $(w)$

Bobot inertia digunakan untuk mengurangi kecepatan pada formula update kecapatan. Pada penelitian ini, cara penentuan nilai $w$ yang digunakan adalah nilai $w$ yang random dan konstan dengan rumus sebagai berikut:

$w=0,1+($ rand $\times 0,4)$

4. Penentuan Nilai Fitness pada Posisi Awal Partikel

Penentuan nilai fitness pada PSO digunakan untuk menentukan posisi individu ( $p$ Best) dan posisi global ( $g$ Best). Nilai fitness yang digunakan dalam penelitian ini adalah fungsi meminimumkan nilai MSE. 


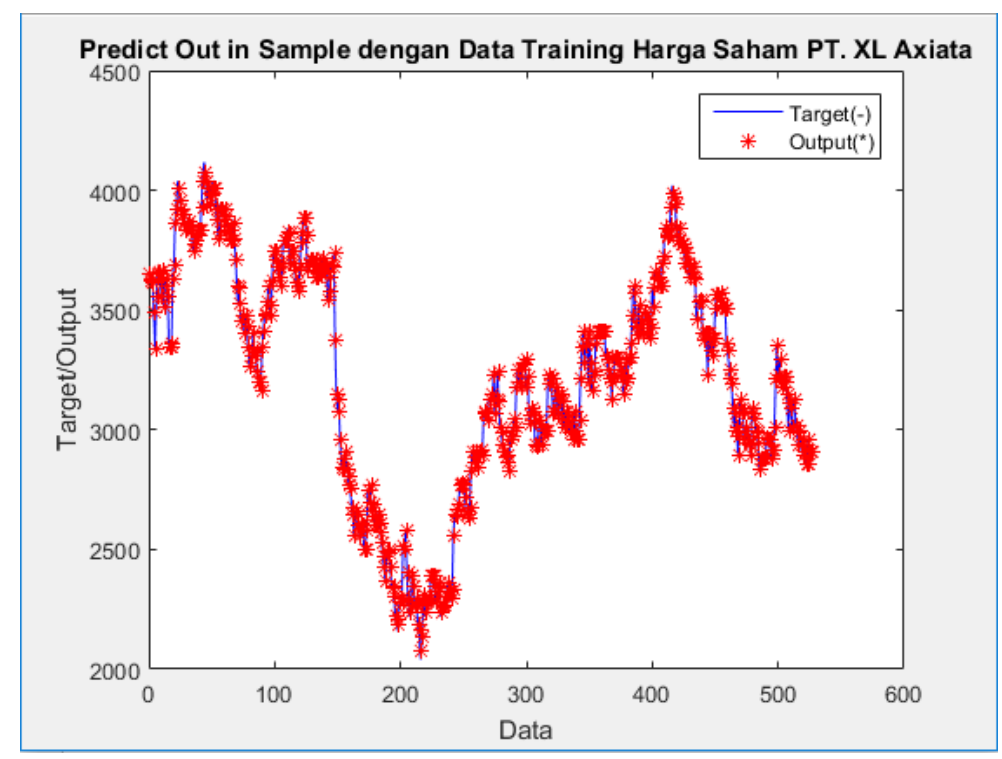

Gambar 2. Prediksi Target dan Output Data Training

Tabel 2. Bobot Akhir Hasil Pelatihan

\begin{tabular}{|l|l|}
\hline Bobot & Keterangan \\
\hline 0,12150 & Bobot input $x_{t-1}$ ke hidden layer 1 \\
\hline$-0,76140$ & Bobot input $x_{t-1}$ ke hidden layer 2 \\
\hline$-0,21711$ & Bobot input $x_{t-1}$ ke hidden layer 3 \\
\hline$-0,89683$ & Bobot input $x_{t-1}$ ke hidden layer 4 \\
\hline 0,058223 & Bobot input $x_{t-1}$ ke hidden layer 5 \\
\hline 0,55992 & Bobot bias ke hidden layer 1 \\
\hline 0,65129 & Bobot bias ke hidden layer 2 \\
\hline$-0,23194$ & Bobot bias ke hidden layer 3 \\
\hline 1,0000 & Bobot bias ke hidden layer 4 \\
\hline$-0,47488$ & Bobot bias ke hidden layer 5 \\
\hline 0,70084 & Bobot input $x_{t-1}$ ke output \\
\hline$-0,24972$ & Bobot bias ke output \\
\hline$-0,73043$ & Bobot hidden layer 1 ke output \\
\hline$-0,99793$ & Bobot hidden layer 2 ke output \\
\hline$-0,98129$ & Bobot hidden layer 3 ke output \\
\hline 0,77331 & Bobot hidden layer 4 ke output \\
\hline$-0,85351$ & Bobot hidden layer 5 ke output \\
\hline
\end{tabular}

5. Inisialisasi Bobot sebagai Partikel PSO

Pada penelitian ini, parameter CFNN yang dioptimasi menggunakan PSO adalah bobot, sehingga dapat dikatakan bahwa bobot merupakan partikel pada PSO. Inisialisasi bobot awal dilakukan sebelum dilakukan proses iterasi pertama kali, jadi inisialisasi bobot awal dilakukan pada iterasi ke-0. Bobot awal diperoleh dengan membangkitkan bilangan random, dimana banyaknya bilangan random sesuai dengan jumlah bobot yang ada dalam jaringan dengan interval pembangkitan bilangan random antara -1 dan 1 . Algoritma akan mencari bobot 
optimal dalam ruang pencarian yang bernilai antara -1 dan 1 . Ketika terdapat nilai bobot yang melebihi nilai -1 dan 1 maka bobot tersebut akan diinisialisasi ulang. Jika melebihi -1 maka akan bernilai sama dengan -1 dan jika melebihi 1 akan bernilai sama dengan 1 . Karena jumlah partikel $(N)$ yang digunakan adalah 20 maka matriks bobot awal yang terbentuk sebanyak 20 .

Setelah membangun arsitektur jaringan CFNN terbaik, maka proses training dapat dilakukan dengan memasukkan data input $\left(x_{t-1}\right)$ dan target $\left(x_{t}\right)$ sebanyak 527 data, sehingga diperoleh hasil seperti pada Gambar 2. Berdasarkan Gambar 2 dapat dilihat bahwa bahwa pelatihan jaringan telah memberikan hasil prediksi cukup akurat yang ditunjukkan oleh kedekatan antara target (data asli $=x_{t}$ ) yang disimbolkan dengan garis dan prediksinya (output $=y_{t}$ ) yang disimbolkan dengan bintang (*). Nilai MAPE yang dihasilkan dari proses training sebesar $1,8248 \%$. Nilai bobot atau parameter yang optimum ditampilkan dalam tabel berikut:

\section{Proses Testing}

Proses testing dilakukan dengan memasukan data testing dan target yaitu sebanyak 226 data kemudian diuji dengan menggunakan bobot akhir yang telah dihasilkan dari proses training. Hasil proses testing adalah sebagai berikut:

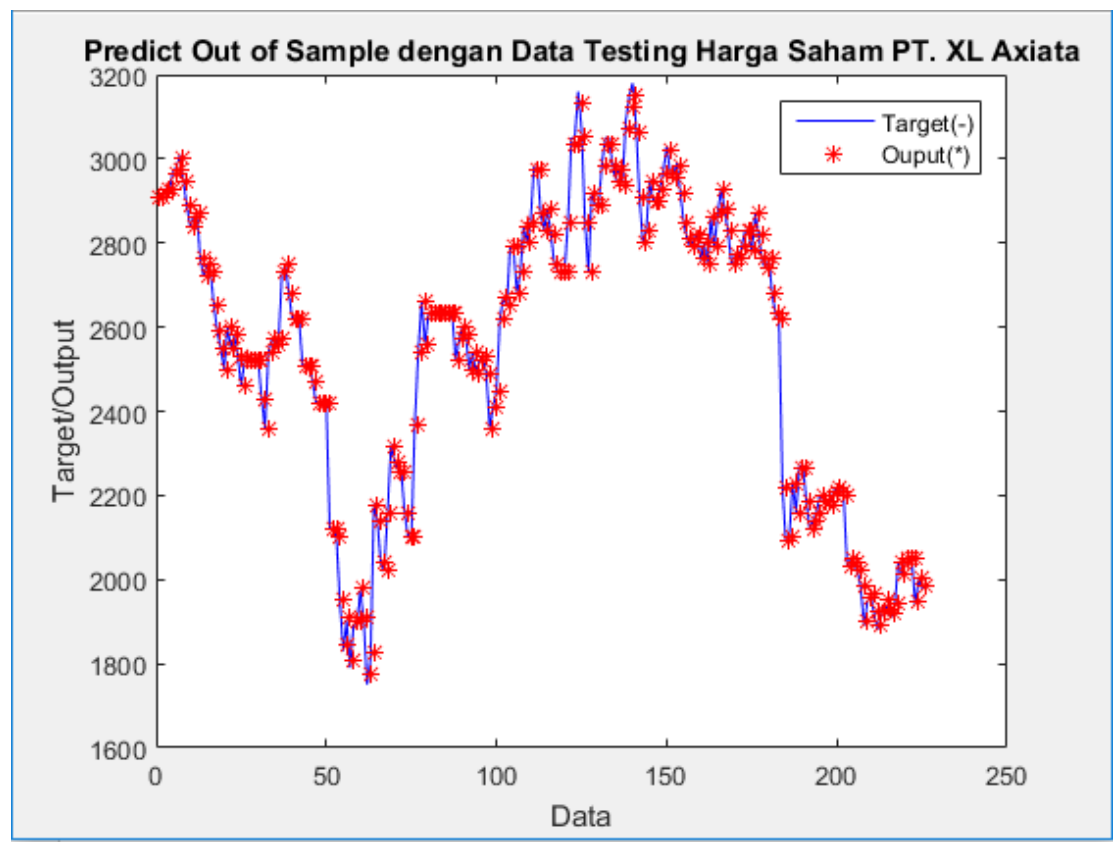

Gambar 3. Prediksi Target dan Output Data Testing

Berdasarkan Gambar 3 dapat dilihat bahwa proses testing telah berhasil memberikan prediksi yang cukup akurat yang ditunjukkan oleh kedekatan antara target (data asli $=x_{t}$ ) yang disimbolkan dengan garis dan prediksinya (output $=y_{t}$ ) yang disimbolkan dengan bintang (*). Nilai MAPE yang dihasilkan dari proses testing sebesar 2,3136\%.

\section{Penentuan Model}

Berdasarkan bobot atau parameter yang optimum dari hasil pelatihan maka dapat diperoleh model CFNN untuk harga saham harian PT. XL Axiata Tbk dapat dituliskan sebagai berikut:

$y=u_{11} x_{1}+w_{o 1}+\sum_{j=1}^{5} w_{j 1}\left(\frac{1-e^{-\left(v_{o j}+\sum_{j=1}^{5} v_{1 j} x_{1}\right)}}{1+e^{\left.-\left(v_{o j}+\sum_{j=1}^{5} v_{1 j} x_{1}\right)\right)}}\right)$

dengan: 


$$
\begin{aligned}
& u_{11}=0,70084 \\
& w_{01}=-0,24972 \\
& w_{11}=-0,73043 \\
& w_{21}=-0,99793 \\
& w_{31}=-0,98129 \\
& w_{41}=0,77331
\end{aligned}
$$$$
w_{51}=-0,85351
$$$$
v_{01}=0,55992
$$$$
v_{02}=0,65129
$$$$
v_{03}=-0,23194
$$$$
v_{04}=1
$$$$
v_{11}=0,1215
$$$$
v_{12}=-0,7614
$$$$
v_{13}=-0,21711
$$$$
v_{14}=-0,89683
$$$$
v_{05}=-0,47488
$$$$
v_{15}=0,058223
$$

\section{Peramalan}

Berikut ini adalah hasil peramalan harga saham harian PT. XL Axiata Tbk untuk 10 langkah kedepan berdasarkan pada model CFNN terbaik yang telah diperoleh sebelumnya adalah sebagai berikut:

Tabel 3. Hasil Peramalan

\begin{tabular}{|c|c|c|c|}
\hline $\begin{array}{c}\text { t Langkah } \\
\text { ke depan }\end{array}$ & $\begin{array}{c}\text { Hasil } \\
\text { Peramalan }\end{array}$ & Aktual & Error \\
\hline 1 & $1.985,335$ & 1980 & 5,3351 \\
\hline 2 & $1.990,369$ & 1980 & 10,3687 \\
\hline 3 & $1.995,131$ & 2020 & 24,8694 \\
\hline 4 & $1.999,635$ & 2040 & 40,3649 \\
\hline 5 & $2.003,911$ & 2140 & 136,0892 \\
\hline 6 & $2.007,958$ & 2190 & 182,0423 \\
\hline 7 & $2.011,804$ & 2250 & 238,1956 \\
\hline 8 & $2.015,451$ & 2250 & 234,5491 \\
\hline 9 & $2.018,926$ & 2200 & 181,0742 \\
\hline 10 & $2.022,229$ & 2110 & 87,7709 \\
\hline \multicolumn{4}{|c|}{ MAPE } \\
\hline
\end{tabular}

Berdasarkan Tabel 3, diperoleh nilai MAPE sebesar 5,2075\%. Dapat dilihat bahwa nilai MAPE yang didapatkan kurang dari 10\%, maka dapat dikatakan keakuratan hasil peramalan masih sangat baik.

\section{KESIMPULAN}

Berdasarkan hasil penelitian, dapat diambil kesimpulan sebagai berikut:

1. Pembagian data training sebesar $70 \%$ dan data testing sebesar $30 \%$ dari total 753 data merupakan pembagian data terbaik karena menghasilkan nilai MAPE training yang relatif lebih kecil daripada pembagian data 60:40, 80:20, 90:10.

2. Arsitektur model terbaik jaringan syaraf tiruan Cascade Forward Neuron Network dibangun dari 1 neuron lapisan input yaitu $x_{t-1}, 5$ neuron lapisan tersembunyi dan 1 neuron lapisan output.

3. Model persamaan CFNN yang dihasilkan adalah sebagai berikut: 


\section{Yunita Pipiet Sugandhi dkk.}

$$
y=u_{11} x_{1}+w_{o 1}+\sum_{j=1}^{5} w_{j 1}\left(\frac{1-e^{-\left(v_{o j}+\sum_{j=1}^{5} v_{1 j} x_{1}\right)}}{1+e^{\left.-\left(v_{o j}+\sum_{j=1}^{5} v_{1 j} x_{1}\right)\right)}}\right)
$$

Model tersebut menghasilkan MAPE training sebesar 1,8248\% dan MAPE testing sebesar 2,3136\%, dimana nilai MAPE tersebut masih di bawah $10 \%$ sehingga dapat dikatakan bahwa model sangat baik untuk dijadikan model prediksi

4. Peramalan harga saham harian PT. XL Axiata Tbk untuk 10 langkah kedepan dengan model terbaik memberikan nilai MAPE sebesar 5,2075\% dimana nilai tersebut masih kurang dari $10 \%$ sehingga dapat dikatakan keakuratan hasil peramalan sangat baik.

\section{DAFTAR PUSTAKA}

Fausett, L. 1994. Fundamental of Neural Network. Prentice Hall. New Jersey.

Haykin, S. 2009. Neural Network and Learning Machines. Third Edition. Pearson Education. New Jersey.

Kusumadewi, S. 2003. Artificial Intellegent (Teknik dan Aplikasinya). Yogyakarta: Graha Ilmu.

Makridarkis, S., \& Wheelwright, S. C. 1999. Metode dan Aplikasi Peramalan. Jakarta: Erlangga.

Santosa, B., \& Jin Ai, T. 2017. Pengantar Metaheuristik Implementasi dengan Matlab2017. Surabaya: ITS Tekno Sains.

Soejoeti, Z. 1987. Analisis Runtun Waktu. Jakarta: Karunika.

Suyanto. 2014. Algoritma Optimasi Deterministik atau Probabilistik. Yogyakarta: Graha Ilmu.

Warsito, B. 2009. Kapita Selekta Statistika Neural Network. Semarang: BP Universitas Diponegoro.

Warsito, B., Santoso, R., Suparti., \& Yasin, H. 2018. Cascade Forward Neural Network for Time Series Prediction. Journal of Physics Vol. 1025.

Wei, W. 2006. Time Analysis Univariate and Multivariate Methods. 2nd Edition. USA: Addison Wesley Publishing Company, Inc.

www.finance.yahoo.com (diakses pada tanggal 9 Februari 2019). 